Article

\title{
Effect of Morphology of Calcium Carbonate on Toughness Behavior and Thermal Stability of Epoxy-Based Composites
}

\author{
Guijun Yang, Young-Jung Heo and Soo-Jin Park * \\ Department of Chemistry, Inha University, Incheon 402-751, Korea; yanggj91@gmail.com (G.Y.); \\ heoyj1211@naver.com (Y.-J.H.) \\ * Correspondence: sjpark@inha.ac.kr
}

Received: 27 February 2019; Accepted: 25 March 2019; Published: 27 March 2019

check for updates

\begin{abstract}
In this study, the modification of an epoxy matrix with different amounts of cube-like and rod-like $\mathrm{CaCO}_{3}$ nanoparticles was investigated. The effects of variations in the morphology of $\mathrm{CaCO}_{3}$ on the mechanical properties and thermal stability of the $\mathrm{CaCO}_{3}$ / epoxy composites were studied. The rod-like $\mathrm{CaCO}_{3}$ /epoxy composites (EP-rod) showed a higher degradation temperature $\left(4.5^{\circ} \mathrm{C}\right.$ ) than neat epoxy. The results showed that the mechanical properties, such as the flexural strength, flexural modulus, and fracture toughness of the epoxy composites with $\mathrm{CaCO}_{3}$ were enhanced by the addition of cube-like and rod-like $\mathrm{CaCO}_{3}$ nanoparticles. Moreover, the mechanical properties of the composites were enhanced by increasing the amount of $\mathrm{CaCO}_{3}$ added but decreased when the filler content reached $2 \%$. The fracture toughness $\mathrm{K}_{\mathrm{ic}}$ and fracture energy release rate $\mathrm{G}_{\mathrm{ic}}$ of cube-like and rod-like $\mathrm{CaCO}_{3}$ /epoxy composites $\left(0.85 / 0.74 \mathrm{MPa} \mathrm{m}^{1 / 2}\right.$ and $318.7 / 229.5 \mathrm{~J} \mathrm{~m}^{-2}$, respectively) is higher than the neat epoxy $\left(0.52 \mathrm{MPa} \mathrm{m}{ }^{1 / 2}\right.$ and $\left.120.48 \mathrm{~J} \mathrm{~m}^{-2}\right)$.
\end{abstract}

Keywords: epoxy composites; calcium carbonate; mechanical properties; thermal properties

\section{Introduction}

Epoxy resin is a kind of thermosetting resin with a molecular structure containing at least two epoxy groups. Due to the good adhesive properties, electrical insulation performance, low dielectric constant and dielectric loss, good heat resistance, and chemical resistance of these resins, they have been widely used in adhesives, electronic instruments, the light industry, coatings, electronics, electrical appliances, electronic packaging, aerospace applications, and other fields [1-3]. However, the application of cured epoxy in the more-demanding fields is limited by its brittleness and poor crack and impact resistance. The commonly used toughening methods include elastomer modification and adding materials with soft molecular structures and epoxy curing agents. These methods effectively improve the toughness of epoxy resins but at the expense of the mechanical modulus and heat resistance of the curing material.

Studies show that incorporating inorganic nanoparticles into the epoxy resin matrix effectively improves the properties of the composite material. The toughening effect of inorganic nanoparticles on epoxy resins is derived from three main aspects. First, the inorganic nanoparticles dispersed in the epoxy resin play a role of transferring stress and reducing stress concentration, thus preventing destructive microcracks from appearing. Second, elongation of the inorganic rigid particle is negligible under the tensile stresses, causing voids on the interface between the matrix and inorganic particles. This blunts the microcracks and impedes the propagation of cracks into destructive cracks. Finally, inorganic nanoparticles have a high specific surface area and active functional groups on the surface of the particles. These functional groups are combined with epoxy resin molecular chains to form a 
network structure that improves the physical and chemical properties of the epoxy resin. Carbon-based materials, such as carbon nanotubes (CNTs), graphite, and carbon black [4-9] can improve the thermal conductivity of the composites due to their intrinsic high thermal conductivity; however, the higher conductivity of this kind of carbon-based composite limits its application in the electronics component packaging field. In order to solve these problems, Zotti et al. [10] used metal-core carbon-shell nanoparticles as nanofiller to fabricate epoxy resin nanocomposites. The metal core/polymeric shell structure nanofiller with magnetic properties enhanced the fracture behaviors significantly. The results show that the effect of nanoparticles on dynamic flexural modulus is negligible (only a $3.6 \%$ increase) at room temperature, but this change is more pronounced at higher temperatures. In recent years, researchers have paid attention to the synthesis and modification of epoxy resins through the use of inorganic nanoparticles, such as $\mathrm{SiO}_{2}$ [11-14], $\mathrm{TiO}_{2}$ [15-18], $\mathrm{Al}_{2} \mathrm{O}_{3}$ [19-22], $\mathrm{ZrO}_{2}$ [23-26], $\mathrm{CaCO}_{3}$ [27-30] and $\mathrm{ZnO}$ [31-34], as fillers. These inorganic nanoparticles are physically or chemically combined with polymers, which enhances the interfacial bonding between the particles and polymer matrix, and thus improves the toughness and strength. Nanometer calcium carbonate is a common inorganic filler that has been widely used in organic macromolecular materials due to its low cost, low toxicity, and low environmental impact. In addition, its low aspect ratio and large surface area may lead to a strong interfacial interaction between the filler and polymer matrix. Li et al. [35] studied the influence of nano- $\mathrm{CaCO}_{3}$ on the mechanical properties of an epoxy resin composite and demonstrated that the impact strength and flexural modulus of the nano- $\mathrm{CaCO}_{3}$ composites improved remarkably when $6 \mathrm{wt} . \%$ of nano- $\mathrm{CaCO}_{3}$ was added. He et al. [36] prepared nano- $\mathrm{CaCO}_{3} /$ epoxy/carbon fiber composites that showed higher thermal stability and mechanical strength. The results showed that a small amount of nano- $\mathrm{CaCO}_{3}(2-6 \mathrm{wt} . \%)$ in the epoxy matrix could significantly increase the thermal stability and mechanical properties. Li et al. [37] modified epoxy resin with ground calcium carbonate (GCC), and the results indicated that the flexural strength and the ratio of the flexural strength to the compressive strength of the epoxy resin mortar were enhanced via the incorporation of GCC. The morphology, size, and amount of nanoparticle dopant directly affect the interfacial interaction between the matrix resin and filler. Zotti et al. [38] reported a sepiolite/epoxy system with different type of sepiolite (hydrated and dehydrated). Compared to the neat epoxy, the sepiolite/epoxy composites show higher $\mathrm{T}_{\mathrm{g}}\left(\approx 6^{\circ} \mathrm{C}\right)$ and enhanced modulus at $35^{\circ} \mathrm{C}$. Moreover, its thermo-mechanical properties and fracture properties were enhanced remarkably with $10 \mathrm{wt} . \%$ of nanofiller. To date, much research has focused on epoxy/inorganic nanoparticle composites, but seldom on the effects of the nanoparticle morphology on the mechanical and thermal properties of epoxy resins. In addition, the distribution of the nanoparticles with different morphologies (such as spherical, fibrous, lamellar, etc.) in the matrix is also different.

In this work, rod-like and cube-like $\mathrm{CaCO}_{3}$ were prepared. Nano- $\mathrm{CaCO}_{3} /$ epoxy composites are subsequently produced by embedding nano- $\mathrm{CaCO}_{3}$ with different morphology into epoxy resin. The influence of nano- $\mathrm{CaCO}_{3}$ morphology on the thermal and mechanical properties of the nano- $\mathrm{CaCO}_{3} /$ epoxy composites was investigated.

\section{Materials and Methods}

\subsection{Materials}

The epoxy resin with bisphenol A diglycidyl ether (185-190 $\mathrm{g} \mathrm{eq}^{-1}$ ) was used as the matrix for the composites and purchased from Kukdo Chemical Company (Seoul, Korea). 4,4'-diaminodiphenylmethane (DDM) was used as the hardener in this work, which was purchased from TCI Company (Tokyo, Japan). Cube-like calcium carbonate $\left(\mathrm{CaCO}_{3}\right)$ was obtained from Sigma-Aldrich Company (Seoul, Korea). All chemicals were not further processed except when mentioned specifically. 


\subsection{Synthesis of Nano- $\mathrm{CaCO}_{3}$ Nanorods}

Typically, $2 \mathrm{~g} \mathrm{CaCO}_{3}$ nanoparticles were dispersed in $100 \mathrm{~mL}$ acetic acid solution by agitating magnetically at $60^{\circ} \mathrm{C}$ for $2 \mathrm{~h}$. Second, $4 \mathrm{~g}$ citric acid was added into the clarified solution and stirred for $12 \mathrm{~h}$ at $60^{\circ} \mathrm{C}$. The clear solution turned into a milky colloid during the process of stirring. The milky colloid was then filtered and washed several times with ethanol and water. The precursor was dried overnight at $40{ }^{\circ} \mathrm{C}$. Finally, the dried precursor was calcinated at $450{ }^{\circ} \mathrm{C}$ for $2 \mathrm{~h}$.

\subsection{Preparation of Nano- $\mathrm{CaCO}_{3} /$ Epoxy Composites}

The $\mathrm{CaCO}_{3}$ /epoxy mixture was prepared by pre-dispersing different morphology and amounts of $\mathrm{CaCO}_{3}$ in acetone under sonication for $30 \mathrm{~min}$. Subsequently, the epoxy resin was added in the above solution under intense electromagnetic stirring at $60^{\circ} \mathrm{C}$. After removing the acetone from the above solution, $17 \mathrm{wt} . \%$ of hardener was added to the $\mathrm{CaCO}_{3}$ /epoxy resin solution under mechanical mixing at $60^{\circ} \mathrm{C}$ for $15 \mathrm{~min}$, and then the mixture underwent a degassing process in a vacuum oven at $60^{\circ} \mathrm{C}$ for $30 \mathrm{~min}$. Finally, the samples were cured according to the following procedure: $110^{\circ} \mathrm{C}$ for $1 \mathrm{~h}$, $140^{\circ} \mathrm{C}$ for $2 \mathrm{~h}$, and post-cured at $170^{\circ} \mathrm{C}$ for $1 \mathrm{~h}$. The preparation process was shown in Scheme 1.

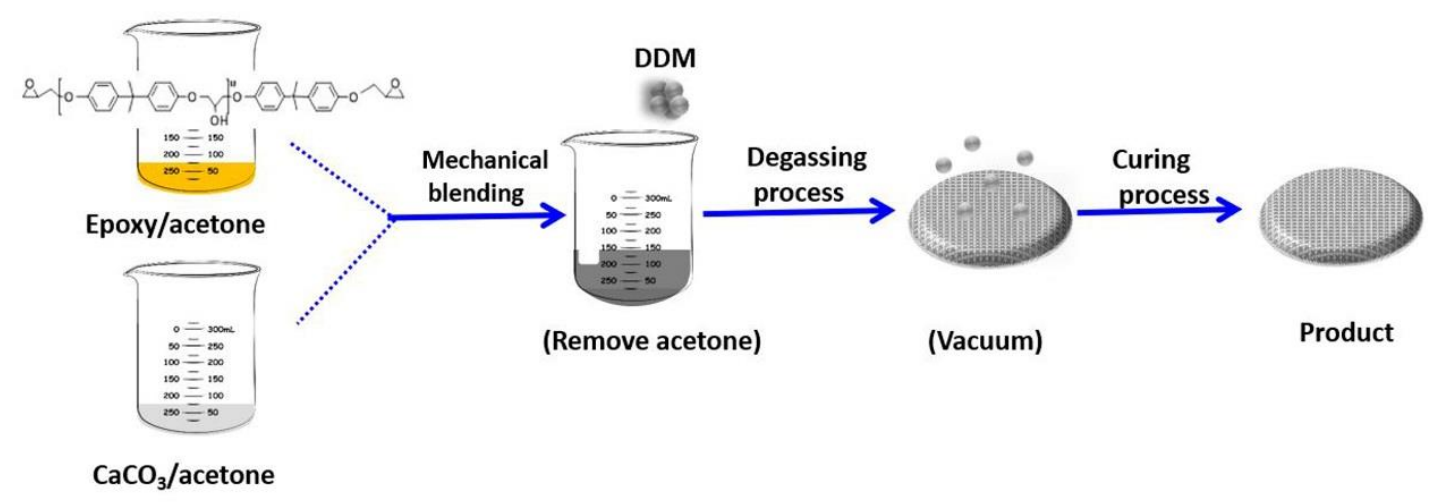

Scheme 1. Preparation of $\mathrm{CaCO}_{3}$ /epoxy composites with different morphology of calcium carbonate.

\subsection{Characterization of Synthetic Compounds}

Thermogravimetric analysis of $\mathrm{CaCO}_{3}$ and nano- $\mathrm{CaCO}_{3}$ /epoxy composites were carried out using NETZSCH (TGA, TG $209 \mathrm{~F} 3$, Bavarian, Germany) with a heating rate of $10{ }^{\circ} \mathrm{C} \mathrm{min}-1$ under a $\mathrm{N}_{2}$ atmosphere from room temperature to $800^{\circ} \mathrm{C}$. The structures of $\mathrm{CaCO}_{3}$ inorganic nanomaterials were characterized using X-ray diffraction (XRD, Panalytical Incorporated, Netherlands) with $\mathrm{Cu} K \alpha$ radiation $(\lambda=1.5405 \AA)$. The cross-sectional of the nano- $\mathrm{CaCO}_{3} /$ epoxy composites were conducted by using scanning electron microscopy (SEM, Model SU8010, Hitachi Co., Ltd., Japan). The critical stress intensity factor $\left(K_{i c}\right)$ of the epoxy and $\mathrm{CaCO}_{3}$ /epoxy was carried out on a universal test machine (Instron Model 1125 mechanical tester, USA) via three-point bending flexure tests and calculated according to the ASTM D5045-95 standard. The schematic of main dimensions of single-edge notch (SEN) samples for the test are shown in Figure S1. The size of the SEN bending sample was $5 \times 10 \times 50 \mathrm{~mm}^{3}$, each with a pre-crack $(5 \mathrm{~mm})$ at the center. The sample was pre-cracked with an electric knife, where the length of pre-crack was measured using Vernier calipers and thickness gauges. Moreover, each group of samples contained at least five samples, and the results were averaged after removing the highest and lowest values during the test. The real photos of the prepared (before testing) and tested sample are shown in Figure S1.

\section{Results}

The XRD patterns of the $\mathrm{CaCO}_{3}$ with nanocube and nanorod morphologies are shown in Figure 1. From the XRD profile, the diffraction peaks at $2 \theta$ values of $23.0^{\circ}, 29.3^{\circ}, 36.0^{\circ}, 39.5^{\circ}, 43.2^{\circ}, 47.3^{\circ}, 48.6^{\circ}$, $57.5^{\circ}, 61.3^{\circ}, 62.7^{\circ}, 65.1^{\circ}, 69.5^{\circ}, 72.6^{\circ}$, and $76.8^{\circ}$, corresponded to the (012), (104), (110), (113), (202), 
(024), (116), (122), (119), (125), (300), (217), (128), and (220) planes of $\mathrm{CaCO}_{3}$ (JCPDS Card NO.001-0837) without any impurity peaks, indicating that the calcium carbonate samples were successfully prepared. In addition, the sharp XRD diffraction peaks indicated that the prepared calcium carbonate sample had good crystallinity.

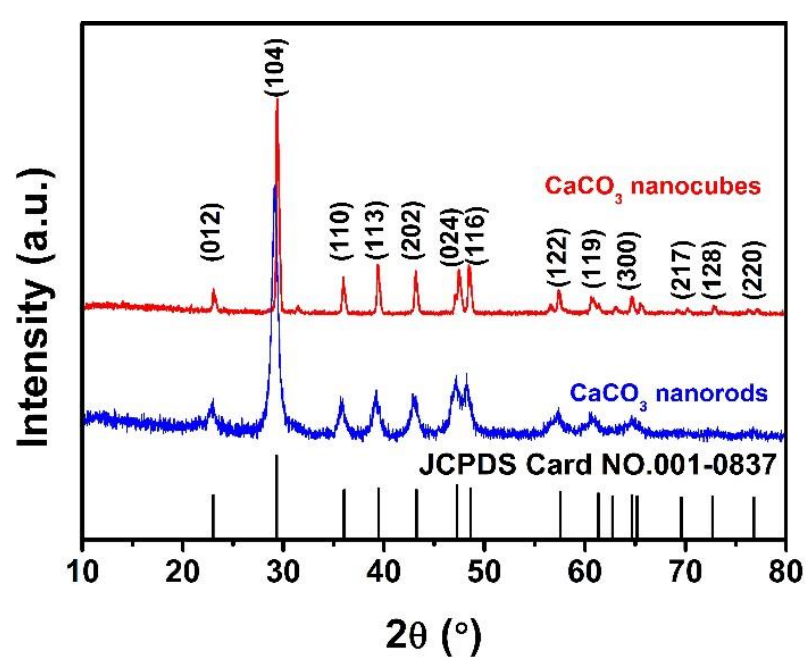

Figure 1. $\mathrm{XRD}$ patterns of $\mathrm{CaCO}_{3}$ nanocubes and $\mathrm{CaCO}_{3}$ nanorods.

Figure 2 shows SEM images of $\mathrm{CaCO}_{3}$ nanorods and nanocubes. The SEM shows that the particles of Figure 2a were cubes with a side length of around $400 \mathrm{~nm}$, while the particles of Figure $2 \mathrm{~b}$ were rods with diameters of 50-100 nm and lengths of around $500 \mathrm{~nm}$. Compared with the cube-like $\mathrm{CaCO}_{3}$, the interface of the rod-like $\mathrm{CaCO}_{3}$ is clearer, the lamination phenomenon was weakened, and the dispersibility was improved. A good dispersion property meant the nanoparticles were uniformly dispersed in the epoxy resin matrix, and the composite material generated more microcracks and plastic deformation when subjected to impact, thereby absorbing more impact energy to achieve an enhanced toughening effect.
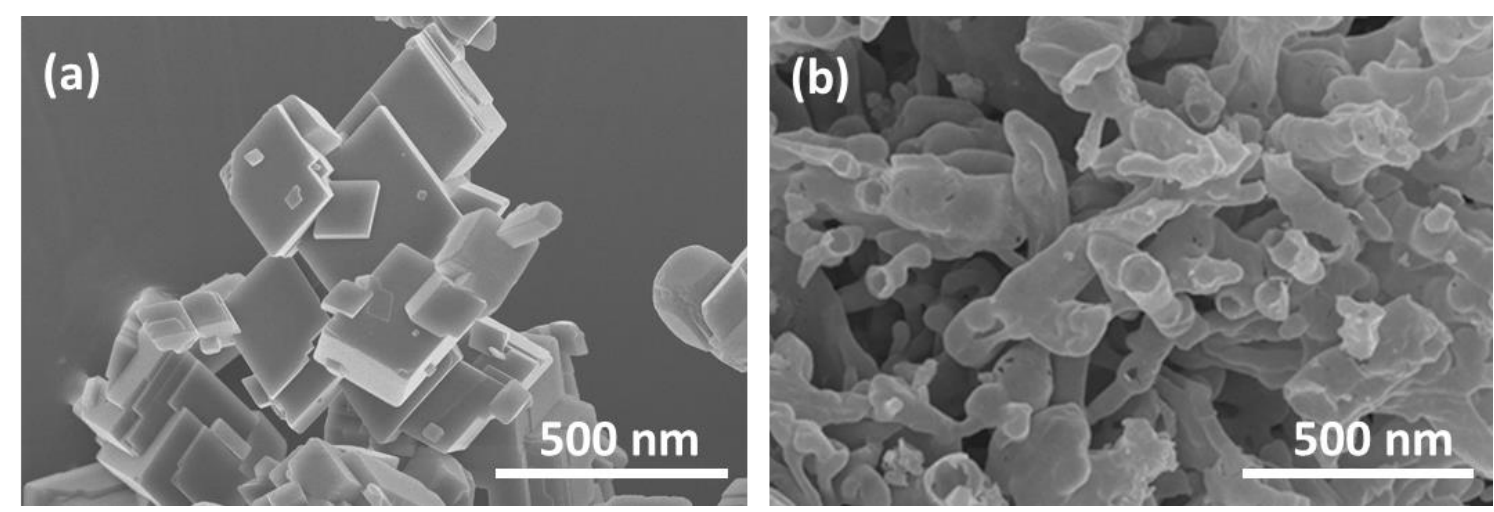

Figure 2. SEM images of (a) $\mathrm{CaCO}_{3}$ nanocubes and (b) $\mathrm{CaCO}_{3}$ nanorods.

The effect of different morphologies and different amounts of $\mathrm{CaCO}_{3}$ on the mechanical properties of epoxy resin were investigated. The formula of flexural strength $\left(\sigma_{f}\right)$ and elastic modulus $\left(E_{b}\right)$ values are as follows:

$$
\begin{gathered}
\sigma_{f}=\frac{3 P L}{2 b d^{2}} \\
E_{b}=\frac{L^{3}}{4 b d^{3}} \frac{\Delta P}{\Delta m}
\end{gathered}
$$


where $P$ is the applied load $(\mathrm{N}), L$ is the span length $(\mathrm{mm}), b$ is the sample width (in $\mathrm{mm}$ ), $d$ is the sample thickness $(\mathrm{mm}), \Delta \mathrm{P}$ is the force change in the linear portion of the load-deflection curve $(\mathrm{N})$, and $\Delta m$ is the corresponding deflection change $(\mathrm{mm})$.

The $\sigma_{f}$ and $E_{b}$ of $\mathrm{CaCO}_{3}$ nanotubes/epoxy composites with different contents of $\mathrm{CaCO}_{3}$ are shown in Figure 3. All composite materials showed better properties than neat epoxy resin. The $\mathrm{CaCO}_{3}$ nanotubes/epoxy composites shows increased $\sigma_{f}$ and $E_{b}$ with the increased $\mathrm{CaCO}_{3}$ content, and then decreased when the $\mathrm{CaCO}_{3}$ content went up to $2 \%$. The enhanced $\sigma_{f}$ and $E_{b}$ properties due to the $\mathrm{CaCO}_{3}$ /epoxy interface interactions transferred the mechanical loads from the matrix to the filler. When the content of $\mathrm{CaCO}_{3}$ was $2 \%$, its mechanical properties decreased mainly due to the crowding effect, which was caused by the excessive amount of $\mathrm{CaCO}_{3}$ additive. When the content of $\mathrm{CaCO}_{3}$ reached 3\%, a large number of aggregation points were generated inside the epoxy resin composites. These aggregation points acted as cracks in the material. When the material was subjected to an external force, stress concentration occurred near the tips of the cracks, and subsequently reduced the mechanical properties.
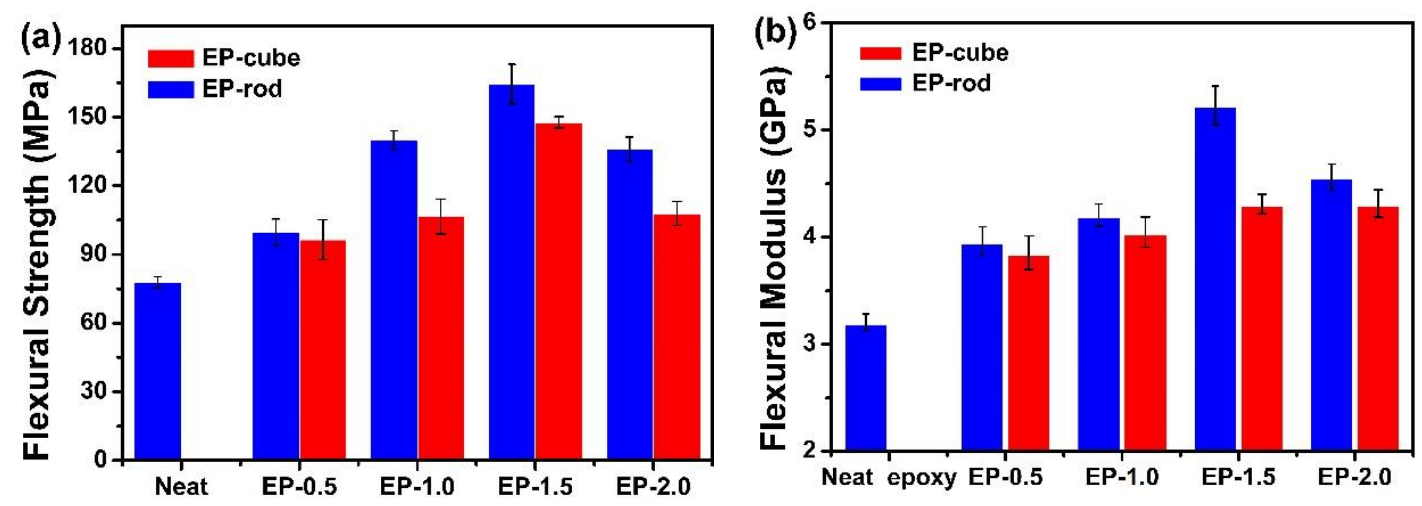

Figure 3. (a) Flexural strength and (b) elastic modulus of $\mathrm{CaCO}_{3}$ nanocubes/epoxy composites and $\mathrm{CaCO}_{3}$ nanorods/epoxy composites as a function of $\mathrm{CaCO}_{3}$ content

The fracture toughness $K_{i c}$ and fracture energy release rate $G_{i c}$ of neat epoxy and its composites were determined via $K_{i c}$ and $G_{i c}$ measurements. The $K_{i c}$ and $G_{i c}$ of the composites with different $\mathrm{CaCO}_{3}$ content was shown in Figure 4 . The $K_{i c}$ value can be calculated as follows:

$$
\begin{gathered}
K_{I C}=\frac{P L}{b d^{\frac{3}{2}}} Y \\
Y=\frac{3(\alpha / d)^{1 / 2}\left[1.99-(\alpha / d)(1-\alpha / d)\left(2.15-3.93 \alpha / d+2.7 \alpha^{2} / d^{2}\right)\right.}{2(1+2 \alpha / d)(1-\alpha / d)^{3 / 2}}
\end{gathered}
$$

where $\alpha$ is the pre-crack width $(\mathrm{mm})$, and $Y$ is the geometrical factor.

The critical strain energy release rate $\left(G_{i c}\right)$ can be calculated as follows:

$$
G_{i c}=\frac{\left(1-v^{2}\right) K_{i c}^{2}}{E}
$$

where the Poisson ratio $v$ for the epoxy is $v=0.3$; and $E$ is Young's modulus, which obtained from the fracture testing.

As can be seen from the Figure 4, the pure resin was very brittle, where its $K_{i c}$ and $G_{i c}$ values were $0.52 \mathrm{MPa} \mathrm{m}^{1 / 2}$ and $120.48 \mathrm{~J} \mathrm{~m}^{-2}$, respectively, while that of the EP-rod and EP-cube reached $0.85 / 0.74 \mathrm{MPa} \mathrm{m}^{1 / 2}$ and $318.7 / 229.5 \mathrm{~J} \mathrm{~m}^{-2}$ at $1.5 \mathrm{wt} . \%$, respectively. The results show that when the content of $\mathrm{CaCO}_{3}$ increased, the $K_{i c}$ and $G_{i c}$ of the composites increased in the range of less than $1.5 \mathrm{wt} . \%$. This increase in fracture properties can be caused by many toughening mechanisms, such 
as crack path deflection, crack pinning, plastic void growth, etc. [39,40]. However, the $K_{i c}$ and $G_{i c}$ of the composite decreased when the content of $\mathrm{CaCO}_{3}$ was more than $1.5 \mathrm{wt} . \%$. This indicates that excessive nano- $\mathrm{CaCO}_{3}$ particles could lead to aggregation in the epoxy resin and reduce the mechanical properties of the epoxy composites, while epoxy composites with a small amount of nano- $\mathrm{CaCO}_{3}$ exhibited enhanced mechanical properties. The result shows that the fillers were expected to lead to higher fracture toughness and fracture energy than neat epoxy, which means that they could withstand stronger shocks and were more durable than neat epoxy. Furthermore, the dispersed nanoparticles formed Van der Waals bonds between the epoxy group of the epoxy resin and the $\mathrm{CaCO}_{3}$ particles, enhancing the constraints between the particles/polymer chain and the polymer chain itself [41]. Thus, the good dispersion of rod-like $\mathrm{CaCO}_{3}$ led to a better mechanical property than cube-like $\mathrm{CaCO}_{3}$.

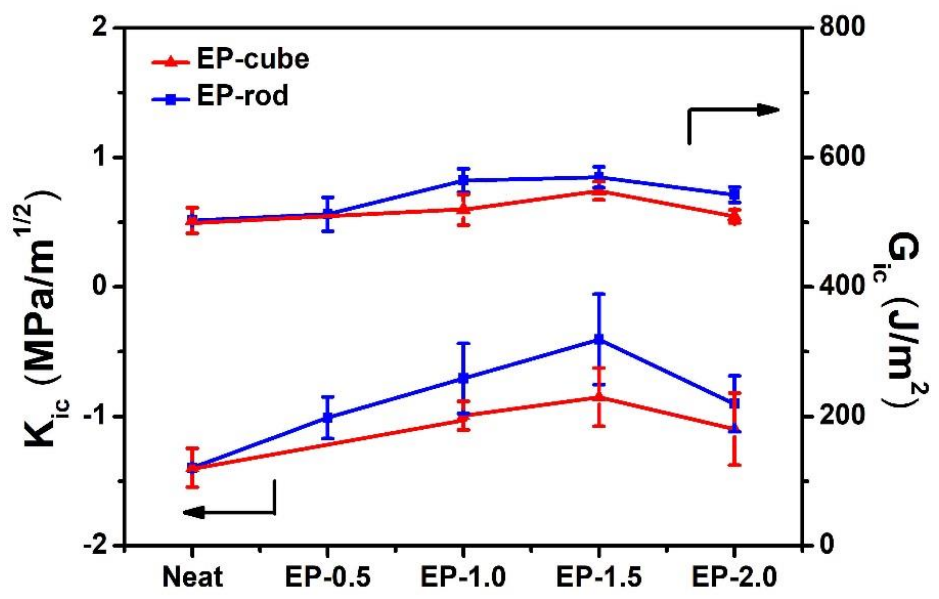

Figure 4. Fracture toughness $\left(K_{i c}\right)$ and fracture energy $\left(G_{i c}\right)$ of neat epoxy and its epoxy composites with different content of $\mathrm{CaCO}_{3}$.

The SEM fractographs of neat epoxy, EP-cube-1.5, and EP-rod-1.5 are shown in Figure 5. Figure 5a shows a smooth cross-section and is a typical brittle fracture morphology of neat epoxy resin. In comparison, the EP-cube-1.5 (Figure 5b) and EP-rod-1.5 (Figure 5c) show rough surfaces, indicating that the crack path of EP-cube-1.5 and EP-rod-1.5 was more complex than neat epoxy resin, which were caused by the crack deflection mechanism. The addition of $\mathrm{CaCO}_{3}$ filler led to crack deflection or crack pinning on the fracture surface. Here, nanoparticles could be considered as an obstacle to crack propagation during the material fracture process, such that this kind of crack propagation will leads to higher energy absorption when the epoxy resin breaks [42-44], which is consistent with the result of Figure 4. Furthermore, the EP-rod-1.5 showed a more undulated surface than EP-cube-1.5, and there were some agglomerates of $\mathrm{CaCO}_{3}$ particles distributed on the fracture surface of EP-cube-1.5. However, this was not found in EP-rod-1.5, indicating that the rod-like $\mathrm{CaCO}_{3}$ had a good dispersing effect in the matrix and formed interface with the epoxy resin.
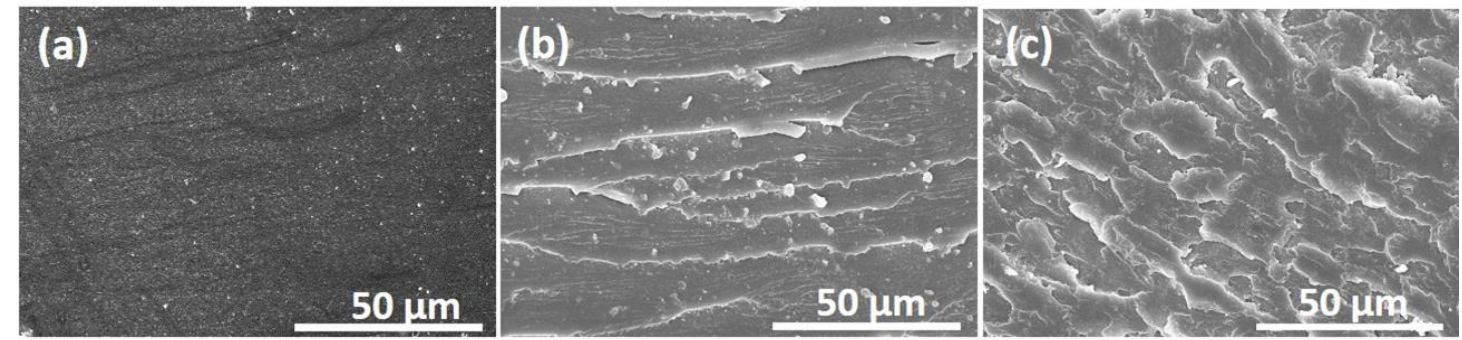

Figure 5. SEM fractographs of (a) neat epoxy, (b) $\mathrm{CaCO}_{3}$ nanocubes/epoxy composites with 1.5 wt.\% $\mathrm{CaCO}_{3}$ nanocubes (EP-cube-1.5), and (c) $\mathrm{CaCO}_{3}$ nanorods/epoxy composites with $1.5 \mathrm{wt} . \% \mathrm{CaCO}_{3}$ nanorod (EP-rod-1.5). 
The thermal stability of the as-prepared neat epoxy resin, EP-cube composites, and EP-rod composites was measured with a TGA measurement and presented in Figure 6. According to the method proposed by Doyle [45], the integral procedural decomposition temperatures (IPDT) of the samples was analyzed. From the IPDT, we could derive the inherent thermal stability of polymer composites during its thermal degradation. The formula for calculating IPDT is as follows $[46,47]$ :

$$
\begin{gathered}
\mathrm{IPDT}=A^{*} K^{*}\left(T_{f}-T_{i}\right)+T_{i} \\
A^{*}=\frac{A_{1}+A_{2}}{A_{1}+A_{2}+A_{3}} \\
K^{*}=\frac{A_{1}+A_{2}}{A_{1}}
\end{gathered}
$$

where $A^{*}$ is the area ratio of the total experimental curve divided by the total TGA thermogram, $K^{*}$ is the coefficient of $A^{*}$, and $T_{i}$ and $T_{f}$ are the initial and final experimental temperature. $A_{1}, A_{2}$, and $A_{3}$ are the areas of the divided regions of the TGA curve, which are indicated in Figure S2.
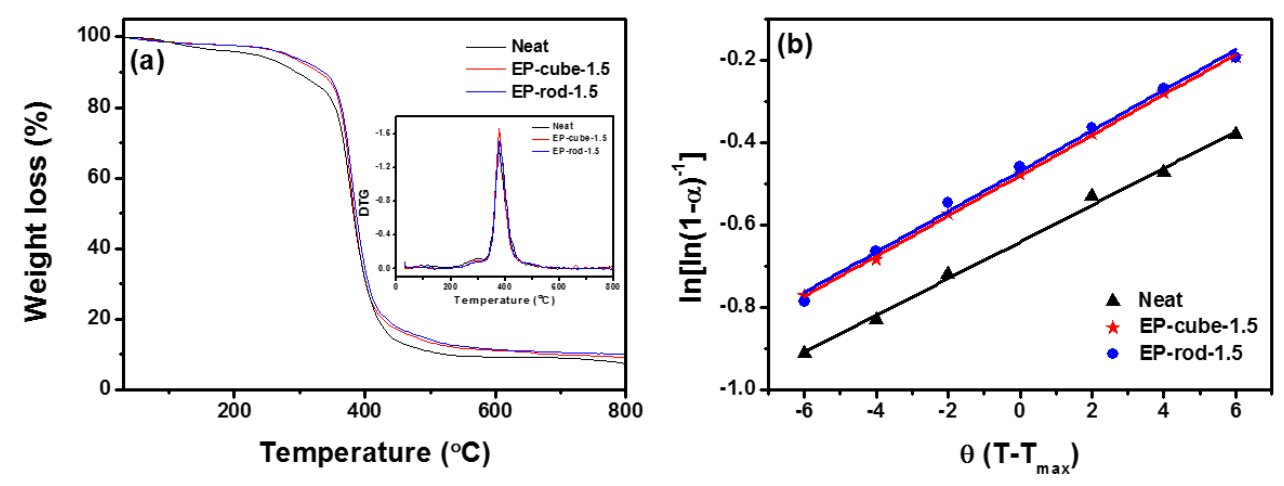

Figure 6. (a) TGA thermograms of the neat epoxy, EP-cube-1.5, and EP-rod-1.5 composites; and (b) plots of $\ln \left[\ln (1-\alpha)^{-1}\right]$ versus $\theta$ by using the Horowitz-Metzger method.

In addition, the decomposition activation energy of epoxy resin composites $\left(E_{t}\right)$ were obtained from the TGA analysis. The $E_{t}$ of epoxy composites was calculated by using the integral method of Horowitz and Metzger [48].

$$
\begin{gathered}
\ln \left[\ln (1-\alpha)^{-1}\right]=\frac{E_{t}}{R T_{\max }^{2}} \theta \\
\alpha=\frac{W_{0}-W_{t}}{W_{0}-W_{\infty}}
\end{gathered}
$$

where $\alpha$ is the decomposition fraction; $T_{\max }$ is the temperature at the maximum weight loss rate; $R$ is the gas constant; $\theta=T-T_{\max }$; and $W_{t}, W_{0}$, and $W_{\infty}$ are the actual, initial, and final masses of the sample. The thermal stability parameters of the as-prepared samples, including IPDT and $E_{t}$ values, are shown in Table 1.

The three samples showed similar TGA curves; however, compared with neat epoxy, the epoxy resin with $1.5 \% \mathrm{CaCO}_{3}$ nanorods (EP-rod-1.5) showed a higher degradation temperature $\left(4.5^{\circ} \mathrm{C}\right)$ than pure epoxy resin. The $T_{5} \%$ of EP-cube composites and EP-rod composites were significantly higher than neat epoxy. However, the temperatures at $T_{50 \%}$ increased slightly. This result shows that the modification of the epoxy resin enhanced the chemical stability of the polymer composites. The IPDT of neat epoxy resin was $476.8^{\circ} \mathrm{C}$, while the EP-rod-1.5 sample showed the highest IPDT value $\left(533.6^{\circ} \mathrm{C}\right)$, indicating an increase in thermal stability. Furthermore, the $E_{t}$ for the decomposition of the EP-cube composites and EP-rod composites were higher than the neat epoxy resin, which meant higher thermal stability and it need more energy for the thermal decomposition process. In addition, the EP-rod composites showed higher $T_{5 \%}$ and $E_{t}$ than the EP-cube composites because rod-like $\mathrm{CaCO}_{3}$ can be more evenly dispersed in the EP resin than cube-like $\mathrm{CaCO}_{3}$, thus the network structure of EP resin 
was more denser and the interaction between the $\mathrm{CaCO}_{3}$ and $\mathrm{EP}$ molecular chains was enhanced, which limited the thermal motion of the molecular chain of EP, increasing the energy required for thermal decomposition of materials, and enhancing the thermal stability of composites. The EP-rod composites showed higher char yields at $800{ }^{\circ} \mathrm{C}$ than the neat epoxy and EP-cube composites, which indicated that rod-like $\mathrm{CaCO}_{3}$ promoted char formation, which prevented heat transfer and enhanced the thermal stability [49].

Table 1. Thermal stability factors of neat epoxy, EP-cube-1.5 and EP-rod-1.5 obtained from TGA thermograms.

\begin{tabular}{cccccccccccc}
\hline Sample & $\begin{array}{c}\text { IDT } \\
\left({ }^{\circ} \mathbf{C}\right)\end{array}$ & $\begin{array}{c}\boldsymbol{T}_{5 \%} \\
\left({ }^{\circ} \mathbf{C}\right)\end{array}$ & $\begin{array}{c}\boldsymbol{T}_{\max } \\
\left({ }^{\circ} \mathbf{C}\right)\end{array}$ & $\boldsymbol{A}_{\mathbf{1}}$ & $\boldsymbol{A}_{\mathbf{2}}$ & $\boldsymbol{A}_{\mathbf{3}}$ & $\boldsymbol{A}^{*}$ & $\boldsymbol{K}^{*}$ & $\begin{array}{c}\text { IPDT } \\
\left({ }^{\circ} \mathbf{C}\right)\end{array}$ & $\begin{array}{c}\boldsymbol{E}_{t} \\
\left(\mathbf{k J ~ m o l} \mathbf{~ m o l}^{-\mathbf{1}}\right)\end{array}$ & $\begin{array}{c}\text { Char Yield at } \\
\mathbf{8 0 0}{ }^{\circ} \mathbf{C}(\mathbf{\%})\end{array}$ \\
\hline Neat epoxy & 376.4 & 230.5 & 381.6 & 32349 & 5689 & 39005 & 0.49 & 1.17 & 476.8 & 156.58 & 7.3 \\
EP-cube-1.5 & 376.7 & 276.4 & 385.4 & 32796 & 6984 & 37226 & 0.51 & 1.21 & 512.5 & 172.18 & 9.0 \\
EP-rod-1.5 & 381.6 & 281.0 & 386.6 & 32670 & 7893 & 36441 & 0.52 & 1.24 & 533.6 & 175.14 & 10.2 \\
\hline
\end{tabular}

\section{Conclusions}

The mechanical properties and thermal stability of epoxy resin with different morphologies and contents of $\mathrm{CaCO}_{3}$ nanoparticles were investigated in this work. The results show that the toughness behavior and thermal stability of epoxy composites with $\mathrm{CaCO}_{3}$ were significantly better than that of neat epoxy resin. Due to the better dispersing effect of rod-like $\mathrm{CaCO}_{3}$ than cube-like $\mathrm{CaCO}_{3}$, the EP-rod $\mathrm{CaCO}_{3}$ composites showed better mechanical properties and thermal stability than that of neat epoxy and EP-cube $\mathrm{CaCO}_{3}$ composites. Observation of the fractured surface using SEM revealed that the EP-rod-1.5 showed a more undulated surface than EP-cube-1.5 and neat epoxy resin, and when cracking occurred, the binding force between the nanoparticles and the polymer chains offset more energy, thus the fracture surface exhibited greater toughness.

Supplementary Materials: The following are available online at http:/ /www.mdpi.com/2227-9717/7/4/178/s1, Figure S1: Dimensions of the sample for fracture toughness test (all dimensions are in $\mathrm{mm}$ ) and the real picture of the prepared (before testing) and tested sample, Figure S2: Schematic representations of $A_{1}, A_{2}$, and $A_{3}$.

Author Contributions: Conceptualization and supervision, G.J.Y. methodology, investigation, writing-original draft preparation; Y.-J.H. supervision; S.-J.P., project administration and funding acquisition.

Funding: This research was funded by the Technological Innovation R\&D Program (grant number S2475164).

Acknowledgments: This work was supported by the Technological Innovation R\&D Program (S2475164) funded by the Small and Medium Business Administration (SMBA, Korea).

Conflicts of Interest: The authors declare no conflict of interest.

\section{References}

1. May, C. Epoxy Resins: Chemistry and Technology; CRC Press: Boca Raton, FL, USA, 1987.

2. Hsieh, T.; Kinloch, A.; Masania, K.; Taylor, A.; Sprenger, S. The mechanisms and mechanics of the toughening of epoxy polymers modified with silica nanoparticles. Polymer 2010, 51, 6284-6294. [CrossRef]

3. Kar, S.; Banthia, A.K. Synthesis and evaluation of liquid amine-terminated polybutadiene rubber and its role in epoxy toughening. J. Appl. Polym. Sci. 2005, 96, 2446-2453. [CrossRef]

4. Wang, M.; Chen, H.; Lin, W.; Li, Z.; Li, Q.; Chen, M.; Meng, F.; Xing, Y.; Yao, Y.; Wong, C.-P. Crack-free and scalable transfer of carbon nanotube arrays into flexible and highly thermal conductive composite film. ACS Appl. Mater. Interfaces 2013, 6, 539-544. [CrossRef] [PubMed]

5. Mittal, G.; Dhand, V.; Rhee, K.Y.; Park, S.-J.; Lee, W.R. A review on carbon nanotubes and graphene as fillers in reinforced polymer nanocomposites. J. Ind. Eng. Chem. 2015, 21, 11-25. [CrossRef]

6. Park, S.-J.; Jeong, H.-J.; Nah, C. A study of oxyfluorination of multi-walled carbon nanotubes on mechanical interfacial properties of epoxy matrix nanocomposites. Mater. Sci. Eng. A 2004, 385, 13-16. [CrossRef]

7. El-Tantawy, F.; Kamada, K.; Ohnabe, H. In situ network structure, electrical and thermal properties of conductive epoxy resin-carbon black composites for electrical heater applications. Mater. Lett. 2002, 56, 112-126. [CrossRef] 
8. Chen, Z.-K.; Yang, J.-P.; Ni, Q.-Q.; Fu, S.-Y.; Huang, Y.-G. Reinforcement of epoxy resins with multi-walled carbon nanotubes for enhancing cryogenic mechanical properties. Polymer 2009, 50, 4753-4759. [CrossRef]

9. Shen, X.-J.; Liu, Y.; Xiao, H.-M.; Feng, Q.-P.; Yu, Z.-Z.; Fu, S.-Y. The reinforcing effect of graphene nanosheets on the cryogenic mechanical properties of epoxy resins. Compos. Sci. Technol. 2012, 72, 1581-1587. [CrossRef]

10. Zotti, A.; Borriello, A.; Zuppolini, S.; Antonucci, V.; Giordano, M.; Pomogailo, A.D.; Lesnichaya, V.A.; Golubeva, N.D.; Bychkov, A.N.; Dzhardimalieva, G.I. Fabrication and characterization of metal-core carbon-shell nanoparticles filling an aeronautical composite matrix. Eur. Polym. J. 2015, 71, 140-151. [CrossRef]

11. Chen, L.; Chai, S.; Liu, K.; Ning, N.; Gao, J.; Liu, Q.; Chen, F.; Fu, Q. Enhanced epoxy/silica composites mechanical properties by introducing graphene oxide to the interface. ACS Appl. Mater. Interfaces 2012, 4, 4398-4404. [CrossRef] [PubMed]

12. Cao, M.-S.; Song, W.-L.; Hou, Z.-L.; Wen, B.; Yuan, J. The effects of temperature and frequency on the dielectric properties, electromagnetic interference shielding and microwave-absorption of short carbon fiber/silica composites. Carbon 2010, 48, 788-796. [CrossRef]

13. Abdollahi, A.; Roghani-Mamaqani, H.; Salami-Kalajahi, M.; Mousavi, A.; Razavi, B.; Shahi, S. Preparation of organic-inorganic hybrid nanocomposites from chemically modified epoxy and novolac resins and silica-attached carbon nanotubes by sol-gel process: Investigation of thermal degradation and stability. Prog. Org. Coat. 2018, 117, 154-165. [CrossRef]

14. Ramezanzadeh, B.; Rostami, M.; Niroumandrad, S. Enhancement of the physical/mechanical properties of an epoxy composite by addition of aluminum nanoparticles through modification with cerium oxides and functionalization by $\mathrm{SiO}_{2}-\mathrm{NH}_{2}$ thin films. Prog. Org. Coat. 2017, 112, 244-253. [CrossRef]

15. Ng, C.; Schadler, L.; Siegel, R. Synthesis and mechanical properties of $\mathrm{TiO}_{2}$-epoxy nanocomposites. Nanostruct. Mater. 1999, 12, 507-510. [CrossRef]

16. Wetzel, B.; Rosso, P.; Haupert, F.; Friedrich, K. Epoxy nanocomposites-Fracture and toughening mechanisms. Eng. Fract. Mech. 2006, 73, 2375-2398. [CrossRef]

17. Goyat, M.; Rana, S.; Halder, S.; Ghosh, P. Facile fabrication of epoxy- $\mathrm{TiO}_{2}$ nanocomposites: A critical analysis of $\mathrm{TiO}_{2}$ impact on mechanical properties and toughening mechanisms. Ultrason Sonochem. 2018, 40, 861-873. [CrossRef]

18. Singh, S.K.; Singh, S.; Kumar, A.; Jain, A. Thermo-mechanical behavior of $\mathrm{TiO}_{2}$ dispersed epoxy composites. Eng. Fract. Mech. 2017, 184, 241-248. [CrossRef]

19. Wang, Z.; Huang, X.; Bai, L.; Du, R.; Liu, Y.; Zhang, Y.; Zhao, G. Effect of micro- $\mathrm{Al}_{2} \mathrm{O}_{3}$ contents on mechanical property of carbon fiber reinforced epoxy matrix composites. Compos. Part B-Eng. 2016, 91, 392-398. [CrossRef]

20. Feng, Y.; Hu, J.; Xue, Y.; He, C.; Zhou, X.; Xie, X.; Ye, Y.; Mai, Y.-W. Simultaneous improvement in the flame resistance and thermal conductivity of epoxy $/ \mathrm{Al}_{2} \mathrm{O}_{3}$ composites by incorporating polymeric flame retardant-functionalized graphene. J. Mater. Chem. A 2017, 5, 13544-13556. [CrossRef]

21. Zakaria, M.R.; Akil, H.M.; Kudus, M.H.A.; Othman, M.B.H. Compressive properties and thermal stability of hybrid carbon nanotube-alumina filled epoxy nanocomposites. Compos. Part B-Eng. 2016, 91, 235-242. [CrossRef]

22. Vaisakh, S.S.; Peer Mohammed, A.A.; Hassanzadeh, M.; Tortorici, J.F.; Metz, R.; Ananthakumar, S. Effect of nano-modified $\mathrm{SiO}_{2} / \mathrm{Al}_{2} \mathrm{O}_{3}$ mixed-matrix micro-composite fillers on thermal, mechanical, and tribological properties of epoxy polymers. Polym. Adv. Technol. 2016, 27, 905-914. [CrossRef]

23. Li, J.; Peng, C.; Li, Z.; Wu, Z.; Li, S. The improvement in cryogenic mechanical properties of nano-ZrO 2 /epoxy composites via surface modification of nano-ZrO 2 . RSC Adv. 2016, 6, 61393-61401. [CrossRef]

24. Khan, R.; Azhar, M.R.; Anis, A.; Alam, M.A.; Boumaza, M.; Al-Zahrani, S.M. Facile synthesis of epoxy nanocomposite coatings using inorganic nanoparticles for enhanced thermo-mechanical properties: A comparative study. J. Coat. Technol. Res. 2016, 13, 159-169. [CrossRef]

25. Zhang, S.; Lv, Y.; Li, J.; Liang, S.; Liu, Z. Mechanical enhancement of zirconia reinforced polyimine nanocomposites. J. Appl. Polym. Sci. 2017, 134, 45183. [CrossRef]

26. Halder, S.; Goyat, M.; Ghosh, P. Morphological, structural, and thermophysical properties of zirconium dioxide-epoxy nanocomposites. High Perform. Polym. 2016, 28, 697-708. [CrossRef]

27. Eskizeybek, V.; Ulus, H.; Kaybal, H.B.; Şahin, Ö.S.; Avc1, A. Static and dynamic mechanical responses of $\mathrm{CaCO}_{3}$ nanoparticle modified epoxy/carbon fiber nanocomposites. Compos. Part B-Eng. 2018, 140, $223-231$. [CrossRef] 
28. Jin, F.-L.; Park, S.-J. Interfacial toughness properties of trifunctional epoxy resins/calcium carbonate nanocomposites. Mater. Sci. Eng. A 2008, 475, 190-193. [CrossRef]

29. Chen, J.-L.; Jin, F.-L.; Park, S.-J. Thermal stability and impact and flexural properties of epoxy resins/epoxidized castor oil/nano- $\mathrm{CaCO}_{3}$ ternary systems. Macromol. Res. 2010, 18, 862-867. [CrossRef]

30. Yu, H.; Wang, L.; Shi, Q.; Jiang, G.; Zhao, Z.; Dong, X. Study on nano-CaCO 3 modified epoxy powder coatings. Prog. Org. Coat. 2006, 55, 296-300. [CrossRef]

31. Nguyen, T.A.; Nguyen, T.V.; Thai, H.; Shi, X. Effect of nanoparticles on the thermal and mechanical properties of epoxy coatings. J. Nanosci. Nanotechnol. 2016, 16, 9874-9881. [CrossRef]

32. Wang, Y.; Ma, J.; Xu, Q.; Zhang, J. Fabrication of antibacterial casein-based ZnO nanocomposite for flexible coatings. Mater. Des. 2017, 113, 240-245. [CrossRef]

33. Koshlaf, E.; Shahsavari, E.; Aburto-Medina, A.; Taha, M.; Haleyur, N.; Makadia, T.H.; Morrison, P.D.; Ball, A.S. Bioremediation potential of diesel-contaminated Libyan soil. Ecotoxicol. Environ. Safe 2016, 133, $297-305$. [CrossRef] [PubMed]

34. Halder, S.; Prasad, T.; Khan, N.I.; Goyat, M.; Chauhan, S.R. Superior mechanical properties of poly vinyl alcohol-assisted ZnO nanoparticle reinforced epoxy composites. Mater. Chem. Phys. 2017, 192, 198-209. [CrossRef]

35. Li, L.; Zou, H.; Shao, L.; Wang, G.; Chen, J. Study on mechanical property of epoxy composite filled with nano-sized calcium carbonate particles. J. Mater. Sci. 2005, 40, 1297-1299. [CrossRef]

36. He, H.; Li, K.; Wang, J.; Sun, G.; Li, Y.; Wang, J. Study on thermal and mechanical properties of nano-calcium carbonate/epoxy composites. Mater. Des. 2011, 32, 4521-4527. [CrossRef]

37. Li, Y.; Liu, X.; Yuan, J.; Wu, M. Toughness improvement of epoxy resin mortar by incorporation of ground calcium carbonate. Constr. Build. Mater. 2015, 100, 122-128. [CrossRef]

38. Zotti, A.; Borriello, A.; Martone, A.; Antonucci, V.; Giordano, M.; Zarrelli, M. Effect of sepiolite filler on mechanical behaviour of a bisphenol A-based epoxy system. Compos. Part B-Eng. 2014, 67, 400-409. [CrossRef]

39. Ulus, H.; Şahin, Ö.S.; Avc1, A. Enhancement of flexural and shear properties of carbon fiber/epoxy hybrid nanocomposites by boron nitride nano particles and carbon nano tube modification. Fibers Polym. 2015, 16, 2627-2635. [CrossRef]

40. Quaresimin, M.; Schulte, K.; Zappalorto, M.; Chandrasekaran, S. Toughening mechanisms in polymer nanocomposites: From experiments to modelling. Compos. Sci. Technol. 2016, 123, 187-204. [CrossRef]

41. Al-Ajaj, I.A.; Abd, M.M.; Jaffer, H.I. Mechanical properties of micro and nano $\mathrm{TiO}_{2}$ /epoxy composites. Int. J. Min. Metall. Eng. 2013, 1, 2320-4060.

42. Kagitci, Y.C.; Tarakcioglu, N. The effect of weld line on tensile strength in a polymer composite part. Int. J. Adv. Manuf. Technol. 2016, 85, 1125-1135. [CrossRef]

43. Fu, S.-Y.; Feng, X.-Q.; Lauke, B.; Mai, Y.-W. Effects of particle size, particle/matrix interface adhesion and particle loading on mechanical properties of particulate-polymer composites. Compos. Part B-Eng. 2008, 39, 933-961. [CrossRef]

44. Ozdemir, N.G.; Zhang, T.; Aspin, I.; Scarpa, F.; Hadavinia, H.; Song, Y. Toughening of carbon fibre reinforced polymer composites with rubber nanoparticles for advanced industrial applications. Express Polym. Lett. 2016, 10, 394-407. [CrossRef]

45. Doyle, C. Estimating thermal stability of experimental polymers by empirical thermogravimetric analysis. Anal. Chem. 1961, 33, 77-79. [CrossRef]

46. Zhang, Y.; Choi, J.R.; Park, S.-J. Thermal conductivity and thermo-physical properties of nanodiamond-attached exfoliated hexagonal boron nitride/epoxy nanocomposites for microelectronics. Compos. Part A Appl. Sci. Manuf. 2017, 101, 227-236. [CrossRef]

47. Kim, S.H.; Heo, Y.-J.; Park, M.; Min, B.-G.; Rhee, K.Y.; Park, S.-J. Effect of hydrophilic graphite flake on thermal conductivity and fracture toughness of basalt fibers/epoxy composites. Compos. Part B-Eng. 2018, 153, 9-16. [CrossRef]

48. Horowitz, H.H.; Metzger, G. A new analysis of thermogravimetric traces. Anal. Chem. 1963, 35, $1464-1468$. [CrossRef]

49. Landel, R.F.; Nielsen, L.E. Mechanical Properties of Polymers and Composites; CRC Press: Boca Raton, FL, USA, 1993.

(C) 2019 by the authors. Licensee MDPI, Basel, Switzerland. This article is an open access article distributed under the terms and conditions of the Creative Commons Attribution (CC BY) license (http:/ / creativecommons.org/licenses/by/4.0/). 